DOI: 10.38136/jgon.791781

\title{
Gebelik Döneminde Kullanılan Farmakolojik ve Farmakolojik Olmayan Yöntemin Laktasyon Döneminde Emzirme Başarısı ve Meme Bașı Yaralanmasına Etkisi
}

\section{The Effect of Pharmacological and Non-Pharmacological Method Used in Pregnancy Period toBreastfeeding and Nipple Injury}

\author{
Derya KANZA GUL \\ Ayça SOLT KIRCA ${ }^{2}$ \\ ${ }^{1}$ Medipol University School of Medicine Health, Istanbul, Turkey \\ ${ }^{2}$ Kirklareli University School of Health, Midwifery Depertmant Kirklareli, Turkey
}

Orcid ID:0000-0001-8879-9299

(1) Orcid ID:0000-0001-6733-5348

Öz

Amaç:Çalışmanın amacı gebelik döneminde kullanılan zeytinyağı ve madecassol kremin laktasyon döneminde emzirme başarısı ve meme başı yaralanmasına etkisini belirlemektir.

Gereç ve Yöntemler: Araştırma Özel Nisa Hastanesi kadın doğum polikliniğinde 1 Ocak 2018- 31 Ocak 2019 tarihleri arasında gebelere ait hastane kayıt bilgileri kullanılarak retrospektif vaka kontrol çalışma olarak gerçekleştirilmiştir. Çalışma son trimester gebelik döneminde memelerine zeytinyağı süren hastalar (zeytinyağı grubu $n=80$ ), memelerine madecassol krem süren hastalar; deney grup 2 (centellaasiaticaekstresi $n=80$ ) ve meme başına herhangi bir bakım uygulamayan hastalar $(n=120)$ olarak gruplandırımış hastalara ait dosyada yer alan sosyo-demografik özellikler ve doğum sonrası 2. ve 5. gün meme durumunu görsel değerlendirme verileri, LATCH emzirme değerlendirme ölçeğindeki veriler ve Görsel kıyaslama ölçeğinde meme başı ağı verileri çalışmada kullanıımıştır.

Bulgular: Postpartum 5. gün meme başı kızarıklğı durumu uygulama yapmayan grubun $\% 51,7$ 'sinde, madecassol krem grubunda $\% 27,5$ ve zeytinyağı grubunda $\% 21,3$ olarak elde edilmiştir $(p<0,001)$. Postpartum 5 . günde meme başı kabuk olma oranı uygulama yapmayan grubun $\% 18,3$, madecassol krem grubunda $\% 8,8$ ve zeytinyağı grubunda $\% 6,3$ olarak elde edilmiştir $(p=0,020)$. Postpartum 5 . gün meme başı ağrısı için GKÖ değerleri uygulama yapmayan grupta zeytinyağı ve madecassol uygulaması yapan diğer iki grup hastaya göre daha yüksek oranda bulunmuştur $(p<0,05)$. Doğum sonrası emzirme başarısının değerlendirildiği 2 . ve 5. gün LACTH değerleri uygulama yapmayan grupta diğer iki gruba göre daha düşük değerlerde olduğu tespit edilmiştir

Sonuç: Çalışmamız, zeytinyağı ve madecassol kremin gebelik döneminden başlayarak kullanımının hiçbir uygulama yapmayan hastalara göre emzirme döneminde meme başı yaralanmasının önlemek için güvenli ve yararlı bir seçim olduğunu göstermektedir.

Anahtar kelimeler: Zeytin yağı, centellaasiatica ekstresi, meme başı yaralanmasl, emzirme

\section{ABSTRACT}

Aim:The aim of the study is to determine the effect of olive oil and madecassol cream used during pregnancy during lactation period on breastfeeding success and nipple injury.

Materials and Methods:It was conducted as a retrospective case-control study between January 1, 2018 and January 31, 2019 at the Private Nisa Hospital obstetrics outpatient clinic. Patients who applied oliveoil totheir breasts during the last trimester pregnancy period (oliveoil group $n=80$ ), patients who applied madecassol cream to their breasts grouped (centellaasiatica extract $n=80$ ) and patients who do not apply any care pernipple $(n=120)$; Socio-demographic characteristics and visual assessment data of breast condition on the 2 nd and 5 th days after birth, in the file belonging to the patients LATCH Data on breastfeeding assessment scale and Nipple pain data on visual analoug scale (VAS) were used in the study.

Results:On the 5 th day postpartum, nipple redness was obtained in $51.7 \%$ of the non-practicing group, $27.5 \%$ in the madecassol cream group and $21.3 \%$ in the olive oil group $(p<0.001)$. On the 5 th day of postpartum, the rate of nipple crust was obtained as $18.3 \%$ in the non-application group, $8.8 \%$ in the madecassol cream group and $6.3 \%$ in the oliveoil group $(\mathrm{p}=0.020)$. On postpartum 5 th day, VAS values for nipple pain and 2nd and 5th day LACTH values on which breastfeeding success was evaluated were found to be lower than the other two groups $(p<0.05)$.

Conclusion:Our study shows that the use of oliveoil and madecassol cream starting from pregnancy period is a safe and useful choice for preventing nipple injury during breastfeeding compared to patients who have not applied any application.

Keywords:Oliveoil, centellaasiatica extract, nipple injury, breastfeeding 


\section{GíRiş}

Günümüzde anne sütünün yeni doğanlar için en ideal beslenme olduğu tüm dünya tarafından kabul edilmektedir (1). Emzirme bebeklerdeki mortalite ve morbitide oranını, çocukluk çağında ortaya çıkan ciddi hastalıkların görülme sıklığını düşürmektedir (2). Dünya sağlık Örgütü (DSÖ) ve Birleşmiş Milletler Uluslararası Çocuklara Yardım Fonu (UNICEF) bebeklerin ilk altı ay boyunca sadece anne sütü ile beslenmesini ve ek gıda ile birlikte iki yaşına kadar sürdürülmesini önermektedir (3).

Emzirmeyi etkileyen birçok faktör bulunmaktadır. Bu faktörler arasında anne yaşı, annenin eğitim durumu, ailenin sosyo-ekonomik düzeyi, çocuk sayısı, annenin emzirme hakkındaki bilgi ve tutumu, annenin ailesi ve yakın çevresinden gördüğü sosyal destek, meme başı yaralanmaları yer almaktadır $(1,2)$. Kadın doğum doktorları, ebeler ve obstetri hemşirelerinin annenin emzirme hakkındaki bilgi ve tutumunu değerlendirmesi, annenin emzirmeye başlamasını sağlamak için uygun müdahaleleri planlamasını ve değerlendirmesine yardımcı olacaktır.

Meme başı yaralanması ve emzirme sorunu ilk 7 günde dünyada görülme sıklığı \%15- 41oranında bildirilmiştir $(3,4)$. Türkiye'de ise bu oran \%24,5 olarak bildirilmiştir (5). Meme başı yaralanmalarında ağrı ile birlikte meme dokusunda kırmızılaşma, beyaz çatlaklar ya da kanama görülebilir $(3,4)$. Meme başı yaralanmasına neden olan en önemli etken yanlış emzirme tekniğidir. Anne doğru emzirme tekniğini uygulamadığı sürece memeye hangi ürünü kullanırsa kullansın (bitkisel, medikal) meme dokusunda iyileşme meydana gelmez. Bu durum emzirmenin kesilmesine yol açar $(6,7)$. Doğum öncesi ve sonrası erken dönemde doğru emzirme pozisyonu ve kapsamlı emzirme eğitimi verilmesi durumunda annelerin meme başı sorunları belirgin olarak azalmaktadır $(8,9)$. Ayrıca hem doğum öncesi hem de doğum sonrası meme başına uygulanan non-farmakolojik (anne sütü vb.) ve farmakolojik yöntemlerin (lanolin, madecassol vb.) neler olduğu ve nasıl kullanılması gerektiği hakkında bilgi verilmesi önem taşımaktadır (10).

Zeytinyağı doğal bir üründür. $A, D, E$ ve $K$ vitaminleri ile kalsiyum, fosfor, potasyum, kükürt, magnezyum, az miktarda demir, bakır, manganez gibi mineraller içermektedir, Flavonoidler antioksidan etkiye sahiptir. Topikal olarak kullanıldığında antibakteriyel ve antifungal etkileri vardır. Atopik dermatit, sedef hastalığı, bebek bezi dermatiti ve yara iyileşmesi gibi dermatolojik hastalıklarda da etkin olduğu vurgulanmaktadır (11).Ayrıca, erken doğmuş bebeklerde parenteral infüzyon için bile güvenli ve yararlı olduğu bulunmuştur (12).

Madecassol \%1 krem, etkin madde olarak $1 \mathrm{~g}$ merhem $10 \mathrm{mg}$ Centellaasiatica'nın titre edilmiş ekstresini içerir. Gotu Kola olarak bilinen Centellaasiatica, halk tıbbında yüzlerce yıldır ve bilimsel olarak yönlendirimiş tıpta kullanılan tıbbi bir bitkidir. Aktif bileşikler arasında asasatikosid, madecassoside, asiatik ve madecassic asitler olmak üzere pentasikliktriterpenler bulunur. Centella asiatica küçük yaralar, hipertrofik yaraların yanı sıra yanıklar, sedef hastalığı ve sklerodermanın tedavisinde de etkilidir. Etki mekanizması, fibroblast proliferasyonunun teşvik edilmesini ve kolajen ve hücre içi fibronektin içeriğinin sentezinin arttııımasın, yeni oluşan cildin gerilme kapasitesinin iyileş- tirilmesini ve ayrıca hipertrofik skar ve keloidlerin enflamatuar fazını inhibe etmeyi içerir (13).

Literatür incelendiğinde, postpartum dönemde emzirmeye bağlı olarak oluşan meme çatlaklarının ya da yaralarının zeytinyağı $(14,15)$, lanolin krem (16), nane jeli (17), gayazulen krem (18), hidrojel pansuman,,silikon meme başı kalkanları,, anne sütü, meme ucunun temiz ve kuru tutulması, sıcak çay kompresi ve sıcak nemli kompres (19) gibi farmakolojik olmayan ve farmakolojik yöntemler kullanılarak azaltıldığına dair bazı deneysel çalışmalar mevcuttur. Ancak kadınların gebelik döneminden başlayarak bu yöntemleri kullanıp ya da kullanmadıklarına göre doğum sonu dönemde emzirme sonucunda oluşabilecek meme başı yaralanmalarının değerlendirildiğini gösteren herhangi bir çalışmaya rastlanmamıştır.

Bu araştırma, gebelik döneminden başlanarak farmakolojik ve farmakolojik olmayan yöntemler kullanılarak memelerine bakım yapan kadınların emzirme sırasında oluşabilecek olan meme çatlaklarının yada yaralarının azaltıımasına etkisini araşıımak amacıyla hastane dosya kayıtlarında yer alan bilgilerden yararlanılarak retrospektif vaka kontrol çalışma olarak yapılmıştır.

\section{GEREÇ VE YÖNTEMLER}

Özel Nisa Hastanesi kadın doğum polikliniğine 1 Ocak 201831 Ocak 2019 tarihleri arasında düzenli olarak takibe gelen gebelere ait bilgiler hastane kayıt sisteminden retrospektif olarak taranmıştır. Bu tarihler arasında 1000 gebe düzenli olarak takibe gelmiştir. 800 gebe sezeryan veya normal doğum yapmıştır. Bebek dostu hastane rutininde takipli bütün gebelere son trimesterde kadın doğum hekimi ve uzman ebelerce aylık doğum ve emzirme semineri verilmektedir. Doğum sonrası 2. ve 5. günlerde anne ve bebek kontrole çağırılarak meme başının durumu görsel olarak, annenin bebeğini nasıl emzirdiği emzirme tanılama ölçüm aracı (LATCH) ile ve meme ağrısı ise Görsel kıyaslama ölçeğiyle (GKÖ) değerlendirilerek hasta dosyasına kayıt edilmektedir. Çalışmanın örneklemini ise bu eğitimlere ve doğum sonrası kontrollere gelen 280 gebeye ait bilgiler oluşturmaktadır.

Dahil edilme kriterleri: 20-40 yaş arasında olması, tek gebelik olması, hastane rutininde yer alan kadın doğum hekimi ve uzman ebeler tarafından düzenlenen aylık doğum ve emzirme seminerine katılmış olması, son trimesterde non-farmakolojik (zeytinyağı), farmakolojik (madecassol krem) veya hiçbir şey kullanmamış olması, postpartum 2. ve 5.günlerde meme durumuna ait bilgilerin kayıt edilmiş olmasıdır.

Dışlanma kriterleri: Illk 24 saat içinde emzirememiş, emzirmeyi etkileyebilecek meme başı anormalliklerin varlığı, emzirme için kontrendikasyon olan hastalık varlığı (HIV vb. bulaşıcı hastalıklar, psikiyatrik hastalıklar), emzirmeyi olumsuz etkileyecek düzenli ilaç kullanımıdır.

Çalışma grupları memelerine zeytinyağı süren $(n=80)$, madecassol krem süren $(n=80)$ ve memelerine herhangi bir uygulama yapmayan $(n=120)$ kadınlardan oluşmak üzere üç grup olarak ayrılmıştır. Hastalara ait dosyada yer alan sosyo-demografik özellikler ve hastanede rutin olarak postpartum 2. ve 5. günlerde memelerin durumunun görsel olarak değerlendi- 
rilmesinde kullanılan LATCH ve ağrının değerlendirilmesi için kullanılan GKÖ'e kayıt edilmiş olan veriler çalışmada kullanılmıştır. Hastalara ait doğum sonrası 2. ve 5. gün meme bilgileri poliklinikte çalışan bebek hemşireleri, ebe veya kadın doğum doktorları tarafından değerlendirilip dosyalara rutin olarak kayıt edilmektedir.

Görsel Kıyaslama Ölçeği (GKÖ): Bond ve Pilowsky tarafından 1966'da ilk kez geliştirilmiş ve kullanıımıştır. GKÖ'nün bir ucunda "ağrısız", diğer ucunda "en kötü ağrıyı" ifade eden $10 \mathrm{~cm}$ 'lik bir cetveldir. GKÖ değerlendirmesinde Ağrısız: $0 \mathrm{~cm}$, Hafif ağrı: $0,5 \mathrm{~cm}-3,0 \mathrm{~cm}$, Orta ağrl: $3,5 \mathrm{~cm}-6,5 \mathrm{~cm}$ ve Şiddetli ağrl: 7,0 cm - 10,0 cm'dır. Hızı sonuçları ve anlaşılması kolay olması nedeniyle akut ağrı şiddetinin belirlenmesi için en uygun ölçek olduğu düşünülmektedir. Bu form Türkçeye Aslan ve Öntürk tarafından uyarlanmıştır (20).

LATCH Ölçeği (LATCH): LATCH emzirme tanılama ölçeği emzirmenin kısa sürede gözlenmesi, emzirme sorunlarının erken tespit edilmesi için kullanılan, emzirmenin objektif olarak değerlendirilmesini sağlayan bir ölçektir. Ayrıca anne ve bebeğin emzirme durumlarını değerlendirerek erken dönemde oluşabilecek emzirme sorunlarının önlenmesi ve başarılı bir emzirmenin sağlanması açısından önemlidir. LATCH emzirme tanımlama ölçüm aracı 1993 yılında Deborah Jensen, Sheila Wallace tarafından geliştirilmişti (21). Demirhan (1997) tarafından Türkçe uyarlanan LATCH Puanlama Sisteminin güvenirliliği ülkemizde Koyun (2001), Yenal ve Okumuş (2003) tarafından yapılmıştır $(22,23,24)$. Bu ölçüm aracı beş değerlendirme kriterinden oluşmaktadır. LATCH bu beş kriterin İngilizce karşılığının ilk harflerinin birleşiminden oluşmuştur. Bu kriterler şu şekilde sıralanmıştır. L: Memeyi tutma (Latch on breast), A: Bebeğin yutma hareketinin görülmesi, duyulması (Audible swallowing), T: Meme ucunun tipi (Type of nipple), C: Annenin meme ve meme ucuna ilişkin rahatlığı ( Comfort Breast/Nipple), H: Bebeği tutuş pozisyonu (Hold/Help). Her madde 0 - 2 puan arasında değerlendirilir. Toplam 10 puandır. Ölçüm aracının kesme noktası yoktur. LATCH puanı yükseldikçe emzirme başarısının yüksek olduğu anlaşılmaktadır.

Veri Toplama Yöntemi: Polikliniğine 1 Ocak 2018- 31 Ocak 2019 tarihleri arasında düzenli olarak takibe gelen gebelere ait bilgiler hastane kayıt sisteminden retrospektif olarak taranmıştır.

\section{Veri Analizi}

Veriler IBM SPSS V23 ile analiz edildi. Normal dağııma uygunluk Kolmogorov Smirnov ile incelendi. Normal dağılım gösteren verilerin karşılaştırımasında tek yönlü varyans analizi ve bağımlı örnekler t testi kullanıldı. Gruplara göre normal dağıım göstermeyen verilerin karşılaştııımasında Kruskal Wallis testi kullanıldı. Kategorik verilerde her bir zaman içinde grup içi karşılaştırmalar için McNemar ve gruplar arası karşılaştırmalarda Ki-kare testi kullanıldı. Normal dağıım gösteren veriler ortalama \pm standart sapma şeklinde gösterildi. Kategorik veriler ise frekans (yüzde) olarak sunuldu. Anlamlılık düzeyi $p<0,05$ olarak alındı.

\section{Araştırmanın Etiği}

Çalışma öncesinde İstanbul Medipol Üniversitesi Klinik Araştırmalar Etik Kurulundan etik kurul onayı alınmıştır (Referans numarası:1084000098-604.01.01-E.14128,19/04/2019). Daha sonra Özel Nisa Hastanesinden yazılı izin alınmıştır. Tüm prosedürler, kurumsal ve/veya ulusal araştırma komitesinin etik standartları ve 1964 Helsinki deklarasyonu ve daha sonraki değişiklikler veya karşılaştırılabilir etik standartlar dikkate alınarak insan katıımcıları içeren çalışmalara ilişkin kurallara uygun olarak gerçekleştirilmiştir.

\section{BULGULAR}

Gruplara göre kilo dağılımları arasında istatistiksel olarak anlamlı bir farklıık vardır $(p=0,010)$. Bunun dışında ki diğer sosyodemografik ve obstetrik özelliklerin dağıımları arasında istatistiksel olarak anlamlı bir farklıık yoktur ( $p>0,050)$ (Tablo 1).

Tablo 1. Grupların sosyodemografik ve obstetrik özellikleri

\begin{tabular}{|c|c|c|c|c|}
\hline & $\begin{array}{l}\text { Uygulama } \\
\text { yapmayan } \\
\text { grup }(n=120)\end{array}$ & $\begin{array}{l}\text { Madecassol } \\
\text { Krem grubu } \\
(\mathrm{n}=80)\end{array}$ & $\begin{array}{l}\text { Zeytinyağı grubu } \\
(\mathrm{n}=80)\end{array}$ & $\mathrm{P}$ \\
\hline Yaş (yıl) & $29,5(23-40)$ & $29,5(20-40)$ & $30(23-40)$ & 0,442 \\
\hline Boy $(\mathrm{cm})$ & $\begin{array}{l}161(90- \\
175)\end{array}$ & $\begin{array}{l}164,5(90- \\
175)\end{array}$ & $162(90-175)$ & 0,096 \\
\hline Kilo $(\mathrm{kg})$ & $70(1-170) a$ & $75(1-170) a b$ & $75(1-170) b$ & $\mathbf{0 , 0 1 0}$ \\
\hline Doğum sayıs1 & $2(1-5)$ & $1(1-5)$ & $2(1-3)$ & 0,068 \\
\hline İşte çalışmak & $\mathrm{n} \quad(\%)$ & n (\%) & $\mathrm{n}(\%)$ & \multirow{3}{*}{0,809} \\
\hline Evet & $41(34,2)$ & $25(31,3)$ & $24(30)$ & \\
\hline Hayır & $79(65,8)$ & $55(68,8)$ & $56(70)$ & \\
\hline $\begin{array}{l}\text { Sürekli devam } \\
\text { eden hastalık }\end{array}$ & & & & \multirow{3}{*}{0,081} \\
\hline Evet & - & - & $2(2,5)$ & \\
\hline Hayır & $120(100)$ & $80(100)$ & $78(97,5)$ & \\
\hline
\end{tabular}

$p<0,05$ a)Kruskal Wallis test istatistiği, a-b: Aynı gruba sahip harfler arasında fark yoktur.

b)Ki-kare test istatistiği,

Meme başı kızarıkığı olma durumu 5. gün gruplara göre farklılık göstermektedir $(p<0,001)$. Uygulama yapmayan grubunun $\% 51,7$ 'sinde meme başı kızarıklığı izlenirken bu oran madecassol krem grubunda $\% 27,5$ ve zeytinyağı grubunda $\% 21,3$ olarak elde edilmiştir. Meme başı kabuk olma durumu 5. günde gruplara göre farklılık göstermektedir $(p=0,020)$. Uygulama yapmayan grupta meme başı kabuk olma oranı $\% 18,3$ iken bu oran madecassol krem grubunda $\% 8,8$ ve zeytinyağı grubunda $\% 6,3$ olarak elde edilmiştir (Tablo 2). Meme başı kızarıklık 2. gün, meme başı çatlağı 2. ve 5. gün, meme başı kabuk olma durumu 2. gün değerleri açısından gruplar arasında istatistiksel faklılık bulunmamaktadır. 
Tablo 2. Doğum sonrası 2. ve 5. gün meme başının değerlendirilmesi

\begin{tabular}{|c|c|c|c|c|c|}
\hline & $\begin{array}{l}\text { Uygulama } \\
\text { yapmayan grup } \\
(\mathrm{n}=120) \\
\mathrm{n} \quad \%\end{array}$ & $\begin{array}{l}\text { Madecassol krem } \\
\text { grubu }(\mathrm{n}=80) \\
\mathrm{n} \quad \%\end{array}$ & $\begin{array}{l}\text { Zeytinyaği } \\
\text { grubu }(\mathrm{n}=80) \\
\mathrm{n} \quad \%\end{array}$ & $\begin{array}{l}\text { Toplam } \\
\text { n } \%\end{array}$ & $P$ \\
\hline $\begin{array}{l}\text { Meme başı kızarıklığ1 } \\
\text { 2. gün } \\
\text { Var } \\
\text { Yok } \\
\text { Meme başı kızarıklğ } 1\end{array}$ & $\begin{array}{ll}17 & (14,2) \\
103 & (85,8)\end{array}$ & $\begin{array}{ll}6 & (7,5) \\
74 & (92,5) \\
\end{array}$ & $\begin{array}{ll}7 & (8,8) \\
73 & (91,3) \\
\end{array}$ & $\begin{array}{ll}30 & (10,7) \\
250 & (89,3)\end{array}$ & 0,262 \\
\hline $\begin{array}{l}\text { Meme başı kizarıkıig1 } \\
\text { 5. gün } \\
\text { Var } \\
\text { Yok } \\
\text { P }\end{array}$ & $\begin{array}{ll}62 & (51,7) \\
58 & (48,3) \\
<0,001 & \end{array}$ & $\begin{array}{l}22 \quad(27,5) \\
58 \quad(72,5) \\
<0,001\end{array}$ & $\begin{array}{l}17 \quad(21,3) \\
63 \quad(78,8) \\
<0,001\end{array}$ & $\begin{array}{r}101 \quad(36,1) \\
179 \quad(63,9) \\
<0,001\end{array}$ & $<0,001$ \\
\hline $\begin{array}{l}\text { Meme başı çatlağ } 1 \\
\text { 2. gün } \\
\text { Var } \\
\text { Yok }\end{array}$ & $\begin{array}{l}11(9,2) \\
109(90,8)\end{array}$ & $\begin{array}{ll}13 & (16,3) \\
67 & (83,8) \\
\end{array}$ & $\begin{array}{ll}5 & (6,3) \\
75 & (93,8) \\
\end{array}$ & $\begin{array}{rr}29 & (10,4) \\
251 & (89,6) \\
\end{array}$ & 0,099 \\
\hline $\begin{array}{l}\text { Meme başı çatlağ } 1 \\
\text { 5. Gün } \\
\text { Var } \\
\text { Yok } \\
\text { P }\end{array}$ & $\begin{array}{l}11(9,2) \\
109(90,8)\end{array}$ & $\begin{array}{cl}8 & (10) \\
72 & (90)\end{array}$ & $\begin{array}{cc}8 & (10) \\
72 & (90) \\
0,250\end{array}$ & $\begin{array}{l}27(9,6) \\
253(90,4)\end{array}$ & 0,973 \\
\hline $\begin{array}{l}\text { Meme başı kabuk } \\
\text { 2. Gün } \\
\text { Var } \\
\text { Yok }\end{array}$ & $\overline{120}(100)$ & $\begin{array}{ll}- & \\
80 & (100)\end{array}$ & $80(100)$ & $280(100)$ & - \\
\hline $\begin{array}{l}\text { Meme başı kabuk } \\
\text { 5. Gün } \\
\text { Var } \\
\text { Yok }\end{array}$ & $\begin{array}{l}22(18,3) \\
98(81,7)\end{array}$ & $\begin{array}{l}7(8,8) \\
73(91,3)\end{array}$ & $\begin{array}{l}5(6,3) \\
75(93,8)\end{array}$ & $\begin{array}{l}34(12,1) \\
246(87,9)\end{array}$ & 0,020 \\
\hline $\mathrm{P}$ & - & - & - & - & \\
\hline
\end{tabular}

Ki-kare test istatistiği $\quad p<0,05$

Doğum sonrası meme başı ağrısı için 2. gün ve 5. gün GKÖ değerleri uygulama yapılmayan grupta grup içi farklılık göstermektedir $(p=0,005)$. 2. gün GKÖ ortalama değeri 4,21 iken 5 . Gün 4,69 olarak elde edilmiştir. Madecassol krem ve zeytinyağı gruplarında ise 2 ve 5 . günlerde GKÖ değerleri açısından grup içi farklılık elde edilmemiştir. Meme başı ağrısı için 5 . gün GKÖ değerleri gruplararası farklılık göstermektedir $(p<0,001)$. Kontrol grubunda ortalama değer $69 \pm 1,95$, madecassol krem grubunda $3,71 \pm 2,32$ ve zeytinyağı grubunda $3,43 \pm 2,21$ olarak elde edilmiştir. Meme başı ağrısı için 2. gün GKÖ değerleri açısından gruplararası farklılık saptanmamıştır (Tablo 3).

Tablo 3. Doğum sonrası 2. gün ve 5. günde Görsel Kıyaslama Ölçeği (GKÖ) değerlerine göre meme başı ağrısı görülme durumu

\begin{tabular}{|l|c|c|c|}
\hline & 2.gün GKÖ & 5.gün GKÖ & $\mathrm{p}^{*}$ \\
\hline Uygulama yapmayan grup & $4,21 \pm 1,83$ & $4,69 \pm 1,95$ & $\mathbf{0 , 0 0 5}^{*}$ \\
\hline Madecassol krem grubu & $3,68 \pm 1,93$ & $3,71 \pm 2,32 \mathrm{a}$ & $0,857^{*}$ \\
\hline & & & \\
Zeytinyağı grubu & $3,75 \pm 1,7$ & $3,43 \pm 2,21 \mathrm{a}$ & $0,161^{*}$ \\
\hline Toplam & $3,93 \pm 1,83$ & $4,05 \pm 2,2$ & \\
\multicolumn{1}{|c|}{$\mathrm{p}^{* *}$} & $0,078^{* *}$ & $<\mathbf{0 , 0 0 1}^{* *}$ & \\
\hline
\end{tabular}

$p<0,05 \quad t^{*}$ : Bağımlı $t$ test istatistiği $F^{* *}$ : Varyans analizi test istatistiği a: Aynı harfe sahip gruplar arasinda fark yoktur.

Doğum sonrası 2. gün ve 5.gün LACTH değerleri gruplara göre farkllık göstermektedir $(p<0,001)$. 2. gün LATCH değeri uygulama yapmayan grupta ortalama değer $5,83 \pm 2,36$, madecassol krem grubunda 6,81 $\pm 2,53$ ve zeytinyağı grubunda $7,23 \pm 2,15$ olarak elde edilmiştir. 5. gün LACTH değerleri ise uygulama yapmayan grupta ortalama değer $6,17 \pm 2,14$, krem grubunda $6,93 \pm 2,44 v e$ zeytinyağı grubunda $7,68 \pm 2,15$ olarak elde edilmiştir(Tablo4).
Tablo 4. Doğum sonrası 2. gün ve 5. günde LACTH değerlerinin karşılaştırması

\begin{tabular}{|l|l|l|l|}
\hline & 2.gün LACTH & 5 .gün LACTH & $\mathrm{p}^{*}$ \\
\hline Uygulama yapılmayan grup & $5,83 \pm 2,36 \mathrm{a}$ & $6,17 \pm 2,14 \mathrm{a}$ & $0,062^{*}$ \\
\hline Madecassol krem grubu & $6,81 \pm 2,53 \mathrm{~b}$ & $6,93 \pm 2,44 \mathrm{ab}$ & $0,550^{*}$ \\
\hline Zeytinyağı grubu & $7,23 \pm 2,15 \mathrm{~b}$ & $7,68 \pm 2,15 \mathrm{~b}$ & $0,062^{*}$ \\
\hline Toplam & $6,51 \pm 2,42$ & $6,81 \pm 2,31$ & \\
\hline \multicolumn{1}{|c|}{$\mathrm{p}^{* *}$} & $<\mathbf{0 , 0 0 1}^{* *}$ & $<\mathbf{0 , 0 0 1}^{* *}$ & \\
\hline
\end{tabular}

$p<0,05 \quad t^{*}$ : Bağımlı $t$ test istatistiği $F^{* *}$ : Varyans analizi test istatistiği a,b: Aynı harfe sahip gruplar arasında istatistiksel fark yoktur.

Bu çalışmada 5. gün meme başında kızarıklık olma durumu ve kabuk olma durumu uygulama yapmayan grupta zeytinyağı ve madecassol uygulaması yapan diğer iki grup hastaya göre daha yüksek oranda bulunmuştur. Postpartum 5. gün meme başı ağrısı için GKÖ değerleri uygulama yapmayan grupta zeytinyağı ve madecassol uygulaması yapan diğer iki grup hastaya göre daha yüksek oranda bulunmuştur. Doğum sonrası emzirme başarısının değerlendirildiği 2 . ve 5 . Gün LACTH değerleri uygulama yapmayan grupta zeytinyağı ve madecassol uygulaması yapan diğer iki gruba göre daha düşük değerlerde olduğu tespit edilmiştir.

\section{TARTIŞMA}

Anne sütü yeni doğanlar için en ideal besin kaynağıdır. Meme başı yaralanmaları ve ağrısı emziren anneler için en büyük sorunlardan biridir ve bu durum emzirmenin kesilmesine yol açar $(6,7)$. Yapılan çalışmalarda meme başı ağrısı ilk bir hafta içinde $\% 45-90$, meme başı çatlağı da ilk 3 günde $\% 15$ - 41oranında bulunmuştur $(3,4)$. Bu araştırmada meme başı çatlağının görülme insidansı (2. günde $\% 10,4 ; 5$. günde $\% 9,6$ ) diğer çalışmalara göre daha az oranda saptanmıştır. Bu farkııı̆ın doğum öncesi hastanede rutin verilen emzirme tekniği eğitimi ve gebelerin gebelik döneminde meme başına uyguladıkları farmakolojik ve farmakolojik olmayan yöntemlerden kaynaklandığını düşünmekteyiz.

Yurt içi ve yurt dışı literatür incelendiğinde meme başı çatlaklarının azaltıımasında zeytinyağının etkisi ile ilgili yapılmış farklı çalışmalar mevcuttur. Cordero ve arkadaşlarının laktasyon dönemindeki 300 kadını değerlendirdikleri çalışmalarında postpartum dönemde meme başına zeytinyağı uygulayan kadınlarda anne sütü uygulayan gruba göre anlamlı oranda meme başı çatlağı az olarak izlenmiştir (25). Kirlek, Akdolun ve Balkayanın 2013 yılında 39 doğum yapan kadın ile yaptıkları çalışmada postpartum dönemde meme başına anne sütünün uygulanmasının meme ağrısını azalttığını ve zeytinyağı uygulamasının meme başı çatlaklarının oluşma olasılığını azalttığııı saptamışlardır(15). Başka bir çalışmada da 56 hastada doğum sonrası hastaya meme başına zeytinyağı ve lanolin krem uygulanmış ve zeytinyağının meme başı çatağını azaltmada çok daha etkin olduğu saptanmıştır(14). Eshigzade ve arkadaşlarının 90 emziren kadında yaptıkları çalışmada zeytinyağı, aloevera özütünün ve anne sütünün meme ağrı şiddetini ve meme fissürünü azalttığını, ancak aloevera özütünün zeytinyağı ve anne sütünden daha etkili saptamışlardır (26). 116 emzirme dönemindeki kadınlarla yapılan başka bir çalışmada ise zeytinyağı kullanan annelerin çoğunluğunun, meme başı çatlağı iyileşme oranının 
daha hızlı olduğunu göstermiştir (27). Bu çalışmada da uygulama yapmayan gruba göre özellikle zeytinyağı grubunda en az oranda meme başı çatlağı olması, meme başı ağıısının daha az olması ve buna bağlı emzirme LACTH değerinin daha fazla olması gebelik öncesi zeytinyağı kullanımının olumlu etkilerinin olduğunu düşündürmektedir.

Madecassol krem fibroblast proliferasyonunu arttırarak kolajen ve hücre içi fibronektin içeriğinin sentezinin arttırımasını, yeni oluşan cildin gerilme kapasitesinin iyileştirilmesini sağlar ve hipertrofik skar ve keloidlerin enflamatuar fazını inhibe ederek gerilemeye engel olur (13). Madecassol krem küçük yaralar, hipertrofik yaraların yanı sıra yanıklar, sedef hastalığı, diyabete bağlı cilt ülserleri ve sklerodermanın tedavisinde etkin olmakla birlikte $(28,29)$ emzirme sonrası meme başı yaralanması üzerine etkisini araştıran herhangi bir çalışma bulunmamaktadır. Bu çalışmada 5. gün meme başında kızarıklık olma durumu ve kabuk olma durumu madecassol uygulaması yapan grupta uygulama yapmayan hasta grubuna göre hastaya göre daha az oranda bulunmuştur. Postpartum 5. gün meme başı ağrısı için GKÖ değerlerinin madecassol uygulaması yapan grupta uygulama yapmayan grupta ki hastalara göre daha az oranda bulunmuştur. Doğum sonrası emzirme başarısının değerlendirildiği 2. ve 5. gün LACTH değerlerinin madecassol uygulaması yapan grupta uygulama yapmayan gruba göre daha yüksek değerlerde olduğu tespit edilmiştir.

Çalışmada bazı sınırlııklar bulunmaktadır. Gruplardaki hasta popülasyonun kilo açısından farklı olması yara iyileşmesi konusunda farklılıklar oluşturabilir. Doğum sonrası meme başı ve emmenin değerlendirilmesinde sezaryen ve normal doğum yapmış hastalar birlikte ele alınmıştır. Genellikle sezaryen sonrası emzirme daha geç dönemde başlamakta ve postoperatif ilk gün daha az emzirme sayısı gözlenmektedir. Bu nedenle araştırmanın doğum tipi, sayısı ve zamanlamasına göre (preterm, postterm, normal doğum, sezaryen doğum) standardize edilmiş tek tip, daha fazla sayıda örneklem grubuyla prospektif yapılması yararlı olacaktır.

\section{SONUÇ}

Çalışmamız, zeytinyağı ve madecassol kremin gebelik döneminden başlayarak kullanımının hiçbir uygulama yapmayan hastalara göre emzirme döneminde meme başı yaralanmasının önlemek için güvenli ve yararlı bir seçim olduğunu göstermektedir. Meme başı yaralanmasının önlenmesi ve yönetiminde zeytinyağının uygulanmasının en iyi stratejinin belirlenmesi için daha fazla çalışma yapıımalıdır.

Çıkar Çatışması: Çalışma kapsamında herhangi bir çıkar çatışması bulunmamaktadır.

Yazar Katkısı: Derya Kanza Gül: Proje geliştirme, Veri Toplama, Makale yazma, Veri Analizi

Ayça Şolt Kırca: Veri Toplama, Veri Analizi, Makale yazma

\section{KAYNAKLAR}

1. World Health Organization (WHO). Protecting, Promoting and Supporting Breastfeeding in Facilities Providing Maternity and Newborn Services: The Revised Baby-Friendly
Hospital Initıatıve, 2018.

2. Optimizing support for breastfeeding as part of obstetric practice. Committee Opinion No. 658. American College of Obstetricians and Gynecologists ObstetGynecol 2016; 127(2):86-92.

3. Victora CG, Bahl R, Barros AJ, França GV, Horton $\mathrm{S}$, Krasevec J, Rollins NC Breastfeeding in the 21st Century: Epidemiology, Mechanisms, and Life long Effect. TheLancet, 2016;387(10017):475-490.

4. Mert $H$, Şirin A Postpartum erken dönemde görülen meme sorunları ve bunu etkileyen faktörlerin incelenmesi. Ege Üniv Hemşire YO Derg,,2010;26(2): 299.

5. Karaçam M, Sağlık M. Breastfeeding problems and interventions performed on problems: systematic review based on studies made in Turkey. Turk Pediatri Ars,2018;53(3):13448.

6. Rollins NC, Bhandari N, Hajeebhoy N, S. Whyinvest, and what it will take to improve breastfeeding practices? TheLancet, 2016;387(30017):491-504.

7. Walker M. Are There Any Cures for Sore Nipples?.Clinical Lactation, 2013; 4(3):105-114.

8. Akyüz A, Kaya T, Şenel N. Annenin Emzirme Davranışının ve Emzirmeyi Etkileyen Durumların Belirlenmesi [Determination of Breastfeeding Behaviors of Mothers and Influencing Factors]. TSK [TAF],2007;6(5):15-19.

9. Riordan J, Wambach K. Breastfeeding and Human Lactation. (4th ed.). Toronto: Jones and Bartlett Publishers, 2010;1:754- 765 .

10. Eksioglu A, Yesil Y, Demir Gungor D, Ceber Turfan E. The Effects of Different Breastfeeding Training Techniques Given for Primiparous Mothers Before Discharge on the Incidence of Cracked Nipples.Breastfeed Med.,2017; 12:311-315.

11. Deshpande GC, Simmer K, Mori T, Croft K. Parenteral lipid emulsions Parenteral lipid emulsions based on olive oil compared with soybeanoil in preterm ( $<28$ weeks' gestation) neonates: a randomised controlled trial. J Pediatr Gastroenterol Nutr., 2009;49(5):619-25.

12. Tomsits E, Pataki M, Tölgyesi A, Fekete G, Rischak K, Szollár L. Safety and efficacy of a lipid emulsion containing a mixture of soybeanoil, medium chain triglycerides, oliveoil, and fishoil: a randomised, double blind clinical trial in premature infants requiring parenteral nutrition. J Pediatr Gastroenterol Nutr., 2010;51: 514-521.

13. Lu L, Ying K, Wei S, et al. Asiaticoside induction for cell-cycleprogression, proliferation and collagen synthesis in human dermal fibroblasts. Intern J Dermatol.,2004;43:801-807.

14. Oğuz S, Işık S, Çakır Güngör A.N., Şeker M and Ogretmen Z. Protective Efficacy of Olive Oil for Sore Nipples during Nursing J Family Med Community Health,2014; (4):1021.

15. Kirlek F, Akdolun Balkaya N. The effects of breast milk and olive oil on prevention of nipple pain and nipple cracks at early postpartum period. Turkish Journal of Research \& Development in Nursing.,2013;15(2):17-34.

16. Powers D, Tapia VB. Women's experiences using a 
nipple shield. J Hum Lact.2004;20:327-334.

17. Thabet HA.,Mourad MA., Alahadal AM., AlsenanyS., AlsaifA. Prevention of Nipple Cracks with Peppermint Water versus Breast Milk in Lactating Primiparous Women Life Science Journal.,2013;10(4):4-5.

18. Api M, Sivri D, Api O, Görgen H, Çetin A, Yayla M. Emziren lohusalarda meme başı çatlaklarının önlenmesinde gayazulen ve anne sütünün etkinliğinin karşılaştıııması: randomize, kontrollü, çift-kör çalışma. J Turk Ger Gynecol Assoc., 2005;6(4):279-284.

19. Dodd V, Chalmers C. Comparing the use of hydrogel dressings to lanolin ointment with lactating mothers. JOGNN.,2003;32(4):486-494.

20. Aslan FE ve Öntürk KZ Ağrı ölçümü ve değerlendirilmesi. Aslan Eti, F. (Ed). Ağrı Doğası ve Kontrolü. Ankara: Akademisyen Tıp kitapevleri; 2014;67-100.

21. Jensen D, Wallace S, Kelsay P. A. Breastfeeding Charting System and DocumentationTool. JOGNN.,1994;23:,27-32.

22. Demirhan F. Sakarya İlinde Emzirmenin Değerlendirilmesi. M.Ü. Sağlık Bilimleri Enstitüsü, Yüksek Lisans Tezi, 1997, İstanbul (Danışman: Prof.Dr. H Pek).

23. Koyun K. LATCH tanılama ölçeğinin kullanımı ve yenidoğan emzirme başarısını inceleyen bir çalışma. Dokuz Eylül Üniversitesi Sağlık Bilimleri Enstitüsü Yüksek Lisans Tezi, 2001, İzmir (Danışman: Prof.Dr. H Okumuş).
24. Okumuş $\mathrm{H}$, Yenal $\mathrm{K}$, LATCH emzirme tanılama aracının güvenirliğini inceleyen bir çalışma. Hemşirelik Araşırma Geliştirme dergisi. 2003;5(1):38-44.

25. Cordero MJ, Villar NM, Barrilao RG, Cortés ME, López AM. Application of Extra Virgin Olive Oil to Prevent Nipple Cracking in Lactating Women. World views Evid Based Nurs.,2015;12(6):364-369.

26. Eshgizade M, Moghaddam MB, Moghaddam HM, Mahmodian A, Mina M.Comparison of the effect of olive oil, aloe vera extract and breast milk on healing of breast fissure in lactating mothers: A randomized clinical trial. Qom Univ Med Sci J.2016;10(3):19-27.

27. Nageeb H, Fadel EA, HassanNH. Olive oil on nipple trauma among lactating mothers. Mansoura Nursing Journal (MNJ). vol.6. No.1 ISSN:18235-2018.

28. Metcalf DG, Bowler PG. Biofilm delays wound healing: A review of the evidence. Burns Trauma.,2015;1:5-12.

29. Qiang Hou, Ming Li, Yan-Hua Lu, Dong-Hong Liu, Cheng-Cun Li.Burn wound healing properties of asiaticoside and madecassoside. Exp Ther Med.,2016;12(3):1269-1274. 